\title{
TIMBER EXPLOITATION RATE IN TROPICAL RAINFOREST ECOSYSTEM OF SOUTHWEST NIGERIA AND ITS IMPLICATIONS ON SUSTAINABLE FOREST MANAGEMENT
}

\author{
ADEKUNLE, V.A.J. ${ }^{1}-$ OLAGOKE, A.O. ${ }^{1}{ }^{*}$ - OGUNDARE, L.F. ${ }^{2}$ \\ ${ }^{I}$ Dept. of Forestry and Wood Technology, Federal University of Technology, \\ P.M.B. 704, Akure, Ondo State, Nigeria 340001 \\ ${ }^{2}$ Ondo State Ministry of Agriculture, Forestry and Fisheries, Forestry and Wildlife Services, \\ Akure, Nigeria \\ *Corresponding author \\ e-mail:woleola@justice.com \\ (Received $12^{\text {th }}$ May 2009; accepted $7^{\text {th }}$ February 2013)
}

\begin{abstract}
Timber exploitation data that are very essential for sustainable management of the forest resources, where available in Nigeria, are not analyzed and studied to provide information on the rate of $\log$ removal from the forest estate. Timber exploitation rate in Nigeria using Ondo State as a case study was examined in this study. Secondary data on the volume and number of economic timber species exploited from the reserved and free areas forests in four forest administrative zones on monthly basis between 2003 and 2005 were collected from the state department of forestry. Analysis was done with student t-test and two-way analysis of variance. The result revealed that the highest number of species, families and stems was exploited in the free areas when compared with what was exploited from the reserves for the three-year period. During the study period, a total of 60 and 57 species were exploited from the free areas and the reserves respectively from the four administrative zones. The total number of stems exploited from both the free areas and reserves totaled 111377 with an estimated volume of $295089.67 \mathrm{~m}^{3}$. A steady increase was recorded in logging activities between year 2003 and 2004 but there was a decline in year 2005. This reveals how fast economic timbers are disappearing from the forests and consequently, how the ecosystem is seriously disturbed during logging activities. Principles for achieving the goals of sustainable forest management (SFM) and urgent conservation measures to mitigate these consequences were suggested.
\end{abstract}

Keywords: Timber exploitation; log removal; illegal logging; forest estate; Sustainable Forest Management; Conservation measures

\section{Introduction}

Towards the tail end of $19^{\text {th }}$ century certain hectares of Nigerian forest was put under reservation when it was realized that the rate of forest exploitation as a new enterprise might result into environmental hazard and scarcity of wood in the future. Ogunlade (1993) noted that one third of Nigeria land area $\left(983,213 \mathrm{~km}^{2}\right)$ is forest from where just $10 \%$ was successfully put under reservation. Nigeria has a total of 1,160 of such constituted forest reserves covering a land area of about $1075 \mathrm{~km}^{2}$. Most of these reserves only exist today on paper (Salami, 2006). All other woodlands apart from the $10 \%$ under reservation are regarded as free areas (Adetula, 2008). A total land area of about $914 \mathrm{~km}^{2}$ is designated as free areas in Nigeria.

Though the federal government of Nigeria, through its body responsible for the management of forest resources, puts deforestation rate to be $3.5 \%$ (Oyebo, 2006), Salami (2006) estimated the present rate of deforestation in Nigeria to be $1.36 \%$ per annum. Forest exploitation had remained a big business to quite a number of people 
with its attendant forest destruction and deforestation right from the colonial era. While felling and sawing of logs are going on, other tangible NTFPs are also harvested by mere collection. These NTFPs include fruits (from Irvingia gabonensis), gums, resins, tannins, dye, medicinal plants, mushroom, snails, and Thaumatoccocus danielii and leaves of Mitragyna stipulosa commonly used for preservation of cola nuts and wrapping. So, exploitation has been going on in Nigerian forest without any deliberate management programmes for more than fifty decades. Although the tropical forest appears luxuriant because new leaves grow continually and there is no dormant season when all the leaves are shed, one should not be deceived to believe that the forest is still there.

In Nigeria today, forest management is at crossroads because the guiding principles of managing the forest sustainably are no more with us. Challenges like illegal activities in the forest, declining manpower and capacity in Forestry Department, inadequate forest patrol, lack of returns from timber felling accruing to local people, outdated forestry laws and regulations and population pressure leading to increased clearing of forest land for cultivation of arable and tree crops are such that pose grave threat to sustainable forest management (SFM) in the country (Adetula, 2008). This SFM, a system of management that gives room to the judicious exploitation and utilization of forest resources without jeopardizing the future, is the pillar behind forest management in developed counties. SFM, however, has been defined as the stewardship and use of forests and forest lands in a way, and at a rate, that maintains their biodiversity, productivity, regeneration capacity, vitality and their potential to fulfill, now and in the future, relevant ecological, economic and social functions, at local, national, and global levels, and that does not cause damage to other ecosystems (Briner, 2004).

There is the dearth of data on annual timber exploitation in Nigeria. Where these data are available, they are not well studied and analyzed. So, rate of forest exploitation could not be compared with the regeneration potential of the natural forest and rate of plantation establishment. This would have formed the premise on which forestry planning and development should rest like in the developed nations that have committed substantial amount of fund to monitor growth and exploitation in their natural forests and plantations. Consequently, there is the need to carry out a field research for the purpose of knowing the rate at which economic tropical hardwood timbers are been removed on daily basis in the State's forest estate. This work therefore assesses the rate of timber exploitation in tropical rainforest ecosystem and its consequences on sustainable forest resources management using Ondo State as a case study.

\section{Methodology}

\section{The study area}

Ondo state covers a landed area of about $14788,728 \mathrm{~km}^{2}$ and lies within longitudes $4^{\circ} 30^{1} \& 6^{\circ} \mathrm{E}$ and latitudes $5^{\circ} 45^{1}$ and latitudes $8^{\circ} 15^{1} \mathrm{~N}$. The climate is the humid subtropical indicating that it is basically within the tropical rainforest zone which is dominated by broadleaved trees that form dense layered stands. The forest is multilayered with dominant trees (whose height could be up to $50 \mathrm{~m}$ or $165 \mathrm{ft}$ ), climbers and lianas. The trees could be seen to be green throughout the year because the temperature and precipitation are sufficiently high for continuous growth. The state has about Sixteen (16) forest reserves out of which thirteen (13) were designated to be viable by the time organized forestry started between 1930 and 1936 in Nigeria. 


\section{Method of data collection}

Secondary data on the volume and the number of economic timber species exploited on the monthly basis between 2003 and 2005 for the reserved and unreserved forests (free areas) in four forest administrative zones - Owo, Idanre, Akure and Ofosu - in the state were collected from the state department of forestry records. The study area covers a total area of about $1273 \mathrm{~km}^{2}$. Data was also collected with the use of interview schedule administered on each of the four Zonal Forest Officers (ZFOs) in the selected zones. The questions were designed to collect information on method of timber harvesting in the zone, effectiveness of log control, problems of log control, suggestion on the sustainable management of the forest resources in the state and the annual revenue from logging activities.

\section{Data analysis}

Data were evaluated using descriptive statistics (frequency count, means and percentages) and graphical representation. The data were analyzed separately for both forest types (reserves and free areas) on monthly basis throughout the period of study. The yearly average of volume and number of trees exploited was determined for each of the zone. The total number of trees felled on species basis was categorized into six classes using an interval of $500(<100 ; 100-500 ; 500-1000 ; 1000-5000 ; 5000-10000$; $>10000)$. The species were distributed into families and the total number of species in each family was determined.

Two-way analysis of variance (ANOVA) was used to test for significant differences in the number of species, families, stems and volume of trees exploited from 2003 to 2005 across the different zones studied. The student t-test was also used to compare and test for significant difference in the number of stems, tree species abundance and family richness, and volume obtained in free areas and the reserves. The analyses were performed using SPSS for windows 13.0 (SPSS, 2003).

Table 1. Number of stems, species and total volume of trees exploited in the reserves and the free areas in the zones from 2003 to 2005

\begin{tabular}{|c|c|c|c|c|}
\hline \multirow[t]{2}{*}{ Zones } & \multirow[t]{2}{*}{ Forest type } & \multicolumn{3}{|c|}{ Variables } \\
\hline & & No. of species & No. of Stems & Volume $\left(\mathrm{m}^{3}\right)$ \\
\hline \multirow[t]{2}{*}{ Ofosu } & Free Areas & 38 & 4589 & 26240.11 \\
\hline & Forest Reserve & 41 & 39278 & 123373.96 \\
\hline \multirow[t]{2}{*}{ Akure } & Free Areas & 51 & 21001 & 50559.18 \\
\hline & Forest Reserve & 43 & 1253 & 3543.72 \\
\hline \multirow[t]{2}{*}{ Owo } & Free Areas & 54 & 31613 & 74735.88 \\
\hline & Forest Reserve & 42 & 5028 & 13446.98 \\
\hline \multirow[t]{2}{*}{ Idanre } & Free Areas & 49 & 3988 & 10493.53 \\
\hline & Forest Reserve & 42 & 5059 & 13812.28 \\
\hline \multirow[t]{2}{*}{ Overall } & Free Areas & 60 & 60775 & 162028.70 \\
\hline & Forest Reserve & 57 & 50602 & 154176.94 \\
\hline Total for Both & & 60 & 111377 & 316205.64 \\
\hline
\end{tabular}

\section{Results and discussion}

The result of this study reveals a total of 111,377 stems $-60,775$ and 50,602 stems from the free areas forest reserves respectively - belonging to 62 species were exploited from the entire study area (Table 1). Figure 1 shows the total number of stems exploited 
form the free areas and the reserves in each of the locations during the period of study. The total volume of timber removed from all the zones for the 3-year period is estimated as $316205.64 \mathrm{~m}^{3}\left(154176.94\right.$ and $162028.70 \mathrm{~m}^{3}$ from the forest reserves and free areas respectively).

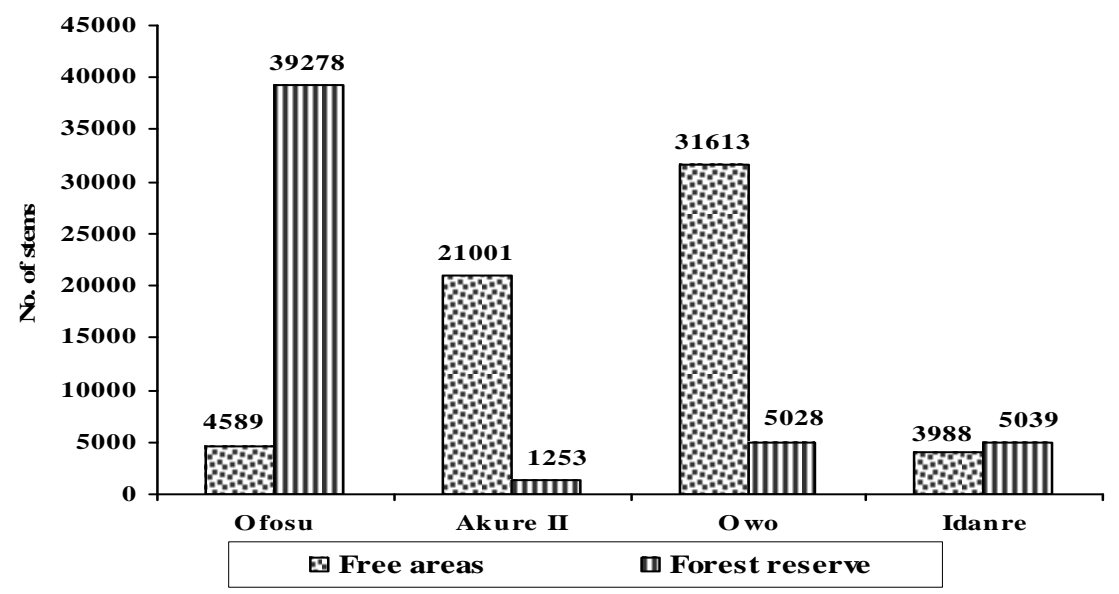

Figure 1. Total number of stems exploited in the study area between 2003 and 2005

Figure 1 shows that highest number of stems was removed in Ofosu zone as far as forest reserve is concern. But, highest number of stems was exploited from Owo zone for the free areas. Generally more wood came out of the reserves in Ofosu and Idanre zones while number of wood from the free areas is more than what was recorded for the reserves in Akure and Idanre. There is significant difference $(\mathrm{P}<0.05)$ in the number of stems from the reserves and the free areas. Also, a significant difference was recorded for number of stems exploited across the four zones from both the reserves and free areas.

The number of stems exploited per species varied considerably. Those that are of high economic value in the timber market were highly sorted for. Hence, they were removed in large number and those not durable were less exploited. From Table 2, the most exploited species are Terminalia superba and Triplochiton scleroxylon, as during the 3-year period from both the free areas and reserves. Apart from Gossweilerodendron balsamiferum, the least exploited species are found not to be popular in the timber market because they are less durable with low density when used as construction materials. The number of stems exploited on species basis from the free areas were greater than that of the forest reserves, except for some species like Afzelia africana, Bombax buonopozense, Cordia millenii, Lovoa trichilioides, Mansonia altissima, Mitragyna ciliata, Nauclea diderrichii, Nesogordonia papaverifera, Sterculia rhinopetala and Terminalia superba whose values were greater in the forest reserves than in the free areas. In the free areas, Triplochiton scleroxylon $(8,151$ stems) was the most exploited species, followed by Terminalia superba $(4,873)$, and the least exploited tree species was Millettia spp. From the forest reserves, the most exploited timber species was Cordia millenii (7,661 stems), followed by Triplochiton scleroxylon with 7,650 stem exploited. Pterocarpus spp was the least exploited species from the forest reserves throughout the period of study. Five species namely Borassus aethiopicum, Gossweilerodendron balsamiferum, Carapa procera, Irvingia spp and Millettia spp were exclusively exploited from the free areas. These important species are already lost 
from the reserves. So, loggers interested in any of these species have to now search for them in the free areas.

Table 2. Classification of Tree Species by Number of Stems Felled from the Entire Study Area between 2003 and 2005

\begin{tabular}{|c|c|c|c|c|c|}
\hline \multicolumn{6}{|c|}{ Number of Stems } \\
\hline$<100$ & $100-500$ & $500-1000$ & $1000-5000$ & $5000-10000$ & $>10000$ \\
\hline $\begin{array}{l}\text { Millettia spp } \\
\text { Gossweilerodendron } \\
\text { balsamiferum } \\
\text { Irvingia wombulu } \\
\text { Borassus } \\
\text { aethiopicum } \\
\text { Bombax spp } \\
\text { Carapa procera } \\
\text { Funtumia elastica } \\
\text { Combretodendron } \\
\text { spp } \\
\text { Combretodendron } \\
\text { macrocarpum } \\
\text { Mitragyna stipulosa } \\
\text { Afromosia elata } \\
\text { Lovoa trichilioides } \\
\text { Guarea cedrata }\end{array}$ & $\begin{array}{l}\text { Distemonanthus } \\
\text { spp } \\
\text { Lonchocarpus } \\
\text { spp. } \\
\text { Sterculia oblonga } \\
\text { Phyllanthus } \\
\text { discoideus } \\
\text { Pterocarpus spp } \\
\text { Entandrophragma } \\
\text { utile } \\
\text { Lophira alata } \\
\text { Berlinia confusa } \\
\text { Mitragyna ciliata } \\
\text { Blighia sapida } \\
\text { Ricinodendron } \\
\text { heudelotii } \\
\text { Fagara spp } \\
\text { Nauclea } \\
\text { diderrichii } \\
\text { Bombax } \\
\text { buonopozense }\end{array}$ & $\begin{array}{l}\text { Amphimas } \\
\text { pterocarpoides } \\
\text { Hannoa spp } \\
\text { Erythrophilleum } \\
\text { spp } \\
\text { Canarium } \\
\text { schweinfurthii } \\
\text { Piptadeniastrum } \\
\text { africana } \\
\text { Daniellia ogea } \\
\text { Entandrophragma } \\
\text { cylindricum }\end{array}$ & $\begin{array}{l}\text { Pycnanthus } \\
\text { angolensis } \\
\text { Other spp. } \\
\text { Lannea } \\
\text { welwitschii } \\
\text { Holoptelia grandis } \\
\text { Chrysophyllum } \\
\text { spp } \\
\text { Nesogordonia } \\
\text { papaverifera } \\
\text { Ficus spp } \\
\text { Terminalia } \\
\text { ivorensis } \\
\text { Celtis spp } \\
\text { Albizia spp } \\
\text { Dialium spp } \\
\text { Pterygota } \\
\text { macrocarpa } \\
\text { Brachystegia } \\
\text { eurycoma } \\
\text { Khaya all species } \\
\text { Alstonia boonei } \\
\text { Melicia excelsa } \\
\text { Antiaris africana } \\
\text { Ceiba pentandra }\end{array}$ & $\begin{array}{l}\text { Afzelia } \\
\text { africana } \\
\text { Sterculia } \\
\text { rhinopetala } \\
\text { Mansonia } \\
\text { altissima } \\
\text { Cordia } \\
\text { millenii }\end{array}$ & $\begin{array}{l}\text { Terminalia } \\
\text { superba } \\
\text { Triplochiton } \\
\text { scleroxylon }\end{array}$ \\
\hline
\end{tabular}

The number of stems and the corresponding volumes exploited on monthly basis varied throughout the period of study is presented in Table 3. The number of stems exploited ranged from 12,726 stems recorded for February to 5,413 stems recorded for October. In term of volume, highest volume was exploited in June, followed by March and the least in October. Generally, logging activities is usually high during the dry season (between September and April of the following year). This could be attributed to the good condition of roads and favourable forest environment during the dry season. Forest roads are usually not motorable throughout the year in Nigeria. While the total mean monthly volume and the number of trees exploited from the forest reserves are 1,435 stems and $2106 \mathrm{~m}^{3}$ respectively, the values for the free areas are $3853 \mathrm{stems}$ and $5025 \mathrm{~m}^{3}$. There was a significant difference in the number of stems exploited across the four study zones but the yearly exploitation in terms of number of stems is not significantly different $(\mathrm{P} \geq 0.05)$. Figures 2 and 3 show the trends in number of stems and volume exploited respectively from the free areas between 2003 and 2005 across the localities. The yearly volume of timber exploited from the free areas also followed the same pattern with that of number of timber exploited. While volumes exploited in 
other localities differed significantly from each other, only Ofosu did not differ from Akure and Owo zones, but a significant difference was observed in volume exploited between Owo and Akure.

Table 3. Number and Volume of Trees Exploited on Monthly Basis in the Entire Study Area

\begin{tabular}{c|c|c|c|c}
\hline Month & \multicolumn{2}{|c|}{ Forest Reserve } & \multicolumn{2}{c}{ Free Areas } \\
& No of Stems & Volume (m3) & No of Stems & Volume (m3) \\
\hline Jan & 5303 & 7554 & 13831 & 18623.51 \\
Feb & 4317 & 5617 & 10844 & 13721.53 \\
Mar & 4985 & 7571 & 13579 & 17701.68 \\
Apr & 6072 & 9039 & 16247 & 18810.761 \\
May & 3411 & 5376 & 9801 & 13529.68 \\
Jun & 6562 & 9838 & 17426 & 26287.99 \\
Jul & 2388 & 3406 & 6278 & 10396.308 \\
Aug & 5372 & 8079 & 14559 & 18906.48 \\
Sept. & 1915 & 2597 & 5051 & 8206.312 \\
Oct. & 3096 & 4793 & 8406 & 10445.5 \\
Nov & 4586 & 6810 & 12452 & 15831.23 \\
Dec & 3664 & 5136 & 10257 & 8438.734 \\
Total & 51671 & 75816 & 138731 & 180899.715 \\
Mean/month & 1,435 & 2106 & 3853 & 5025 \\
\hline
\end{tabular}

The result of the Analysis of Variance (ANOVA) for the free areas shown in Table 4 revealed that the number of timber species exploited differed significantly $(\mathrm{P} \leq 0.05)$ both across the zones and the years. But the result for mean separation shows that there was no considerable variation $(\mathrm{P}>0.05)$ among Ofosu, Akure and Owo zones. In this table also, the number of timber species exploited in 2004 did not differ from what was exploited in 2003 and 2005 significantly, but there was significant difference in the number exploited in 2003 and 2005. For the number of families exploited, the ANOVA result followed the same pattern across the sites with that of number of timber species exploited. Yearly exploitation of families differed significantly $(\mathrm{P} \leq 0.05)$ and there was considerable difference in the values obtained for 2003 and 2004. The results of the analysis of variance (ANOVA) on the variables obtained from the forest reserves are presented in Table 5. Except for the volume of timber exploited from the forest reserves, there is no significant difference $(\mathrm{P} \geq 0.05)$ in the other three variables from 2003 to 2005 . There was a significant difference $(P \leq 0.05)$ in the volume of timber exploited in 2003 and 2004 while the volume of timber exploited in 2005 did not differ significantly with that of 2003 and 2004. The results across the zones show that there were no significant differences in volume exploited except with only Ofosu having its volume significantly different $(\mathrm{P} \leq 0.05)$ from other zones. It was further discovered that the number of species, families, stems and volumes of trees exploited in all the other locations are not significantly different $(\mathrm{P} \geq 0.05)$.

Timber exploitation in the tropical rainforest if not well planned is very deleterious to the environment and biological diversity conservation (Fuwape, 2001). Logging activities directly influence plant diversity and composition or sustainability of forest production through soil or forest floor disturbance (e.g., erosion, compaction, root damage), death of propagule sources (seeds, seedlings, rootstocks), altered habitat structure, removal of nutrients, or altered microclimate (Reich et al., 2001). All the activities involved during logging are contributing directly to ecosystem disturbance. 
Untargeted plants are usually damaged by falling trees, plants are clear cut during transportation and skidding and tractors and timber trucks cause compaction of soils. The habitats of many species of wild animals are also destroyed leading to reduction in wildlife diversity and abundance (Brown and Gurevitch, 2004). The increasing rate of timber exploitation from the free areas and reserves as revealed in this study has led to the unrealization of sustainable forest management in the state. There is generally high rate of indiscriminate logging, over allocation of reserves to contractors, reckless of felling in allocated plots and uncontrolled felling of trees in frees areas. Okpo (1996) asserted that the very high demand for timber products has resulted in the overexploitation and complete devastation of the standing stock of indigenous hardwood species in Nigeria.

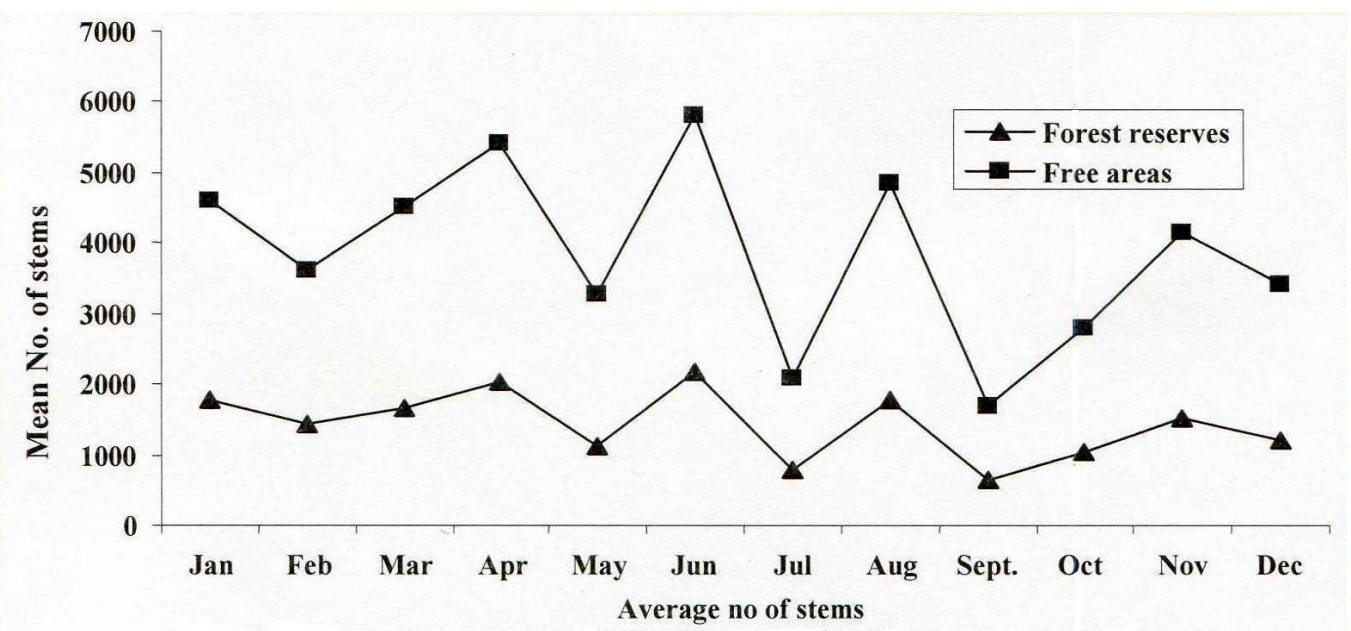

Figure 2. Average number of stems exploited in free areas and the reserves on monthly basis

It should be noted however that the result of this study was based on available records in the state forestry service on legally felled logs. Data on the quantity and quality of timber illegal extracted from the forest are not available. Illegal logging is very prevalent in developing countries today. So what is taken out of the forest estate illegally could in certain circumstance be even more than what is legally removed.

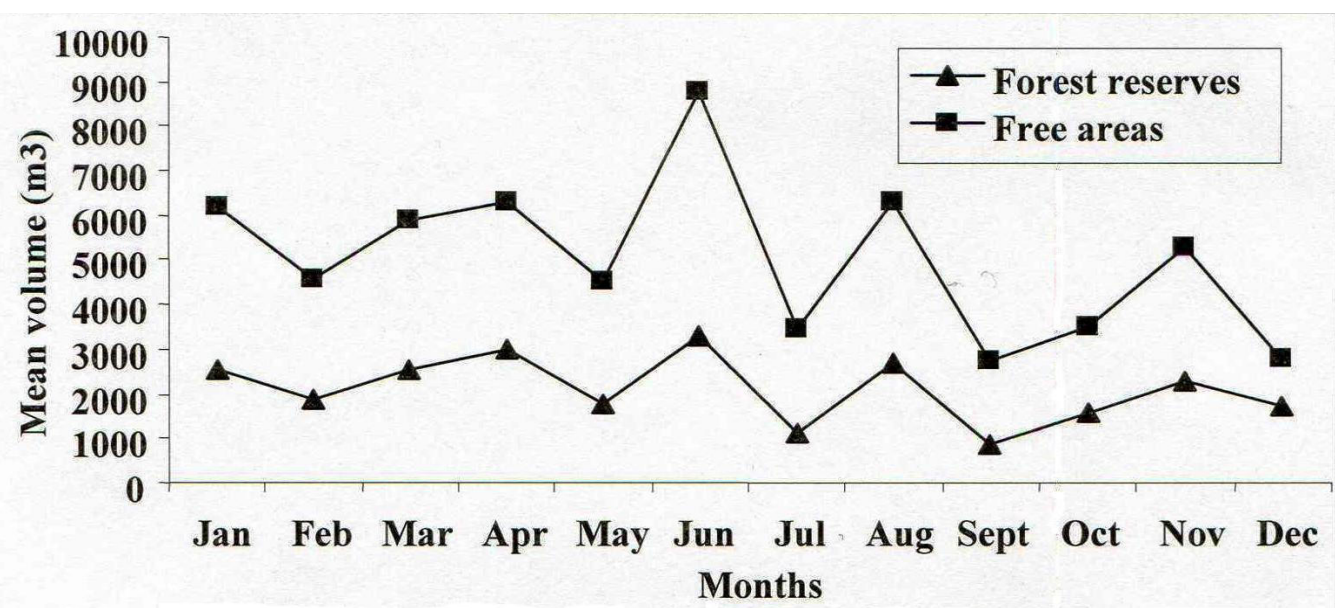

Figure 3. Average volume of timber $\left(\mathrm{m}^{3}\right)$ exploited in free areas and the reserves on monthly basis 
Some of the identified factors responsible for such illegal removal include corruption, youth unemployment, and inefficiency of log control unit of the government and weak enforcement of forest laws. In the study area, armed gangsters had constituted themselves into a militant groups behaving like private army. They have found illegal felling to be a very lucrative business to the extent that unarmed uniformed forestry staff that has the mandate to protect the forest cannot put them under control. As a result, a Joint Task Force on Forestry (with some armed policemen and military men) has to be set up in the state. They are to provide security back up for the Department of forestry to put in check these armed militant groups multiplying daily in the State (Adetula, 2008). Another popular mean of illegal tree removal (including undersized trees) is flitching which is the illegal conversion of logs into planks at felling sites without taking it to the sawmill. These are serious setbacks to SFM in the state.

The results of this study revealed that more timbers were exploited in the free areas than in the forest reserves. This supported the claim of Oyebo (2006) that the rate of degradation in the free areas (areas outside forest reserves) is more than twice the areas being apportioned to be forest estates in Nigeria. This could be attributed to the limited control of the state government on logging activities in the free areas. Also, Falaye et al. (2006) asserted that only few forest allotters had forest allocation in the forest reserves. So, other timber contractors who could not afford the cost of securing allocation in the reserve usually search for wood in the free areas. Akindele and Fuwape (1998) attributed the lower proportion of timber harvests from the forest reserves to the control of the state departments of forestry on timber resources within the forest reserves. Also, the total volume of trees exploited from the forest reserves is less than what was exploited in the free areas as a result of the stringent condition given by the state forestry department to loggers in the reserves. The enforcement of the logging policy of not cutting any tree whose dbh is less than $48 \mathrm{~cm}$ also contributed to the fewer number of stems and volume from the reserves when compared with the free areas.

Variation in the number of stems exploited for each of the species gave an indication that timber contactors operating in the free areas and the reserves have preference for some species. They prefer the most economic, durable and high quality timber over the less durable ones. This is in conformity with the report of Akindele and Fuwape (1998) that timber merchants are very selective in terms of tree species they search for and fell. This was manifested in their preference for species like Triplochiton scleroxylon (Obeche), Terminalia superba (Afara), Afzelia africana (Apa), Mansonia altissima (Ofun), Melicia excelsa (Iroko) and the mahoganies (Khaya spp). The number of individual of these species exploited in the study area is very enormous because they are highly durable. They are good construction materials, raw materials for panel products, venners production, and future items. They are of high value in the international market. These species are critically sought for by loggers to the extent that under-girths are felled anywhere they are found contrary to Nigeria logging policy. Today, these important hardwood timber species are not only rare, but they are seriously threatened with extinction. This was the responsible for why their felling was banned in some States of Nigeria (FORMECU, 1999). Their relative abundance was reported to be less than 5/ha in tropical rainforest ecosystem of southwest Nigeria (Adekunle, 2006; Onyekwelu et al., 2005). 
Table 4. Comparison of the number of species, families and stems and volume of timber exploited ( \pm S.E) in the free areas between 2003 and 2005 across the four forest administrative zones

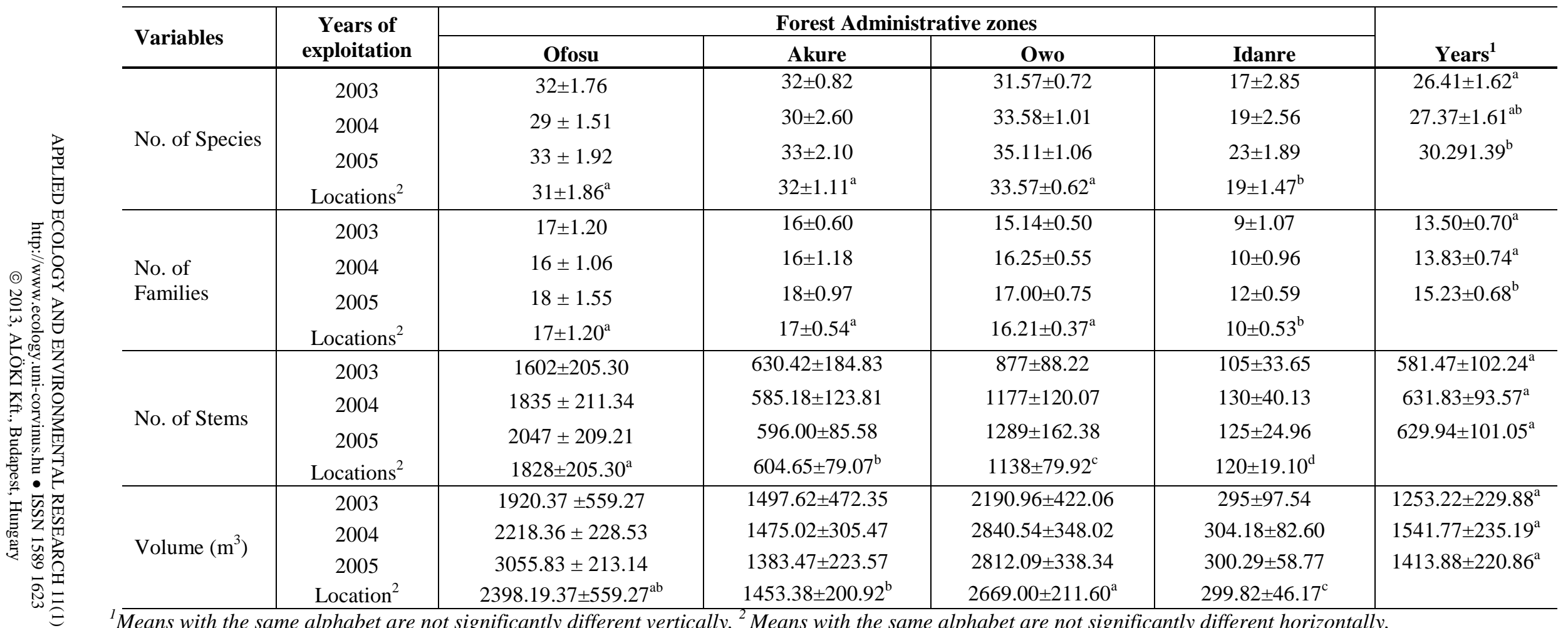


Table 5. Comparison of the number of species, families and stems and volume of timber exploited ( \pm S.E.) in the forest reserves between 2003 and 2005 across the four forest administrative zones

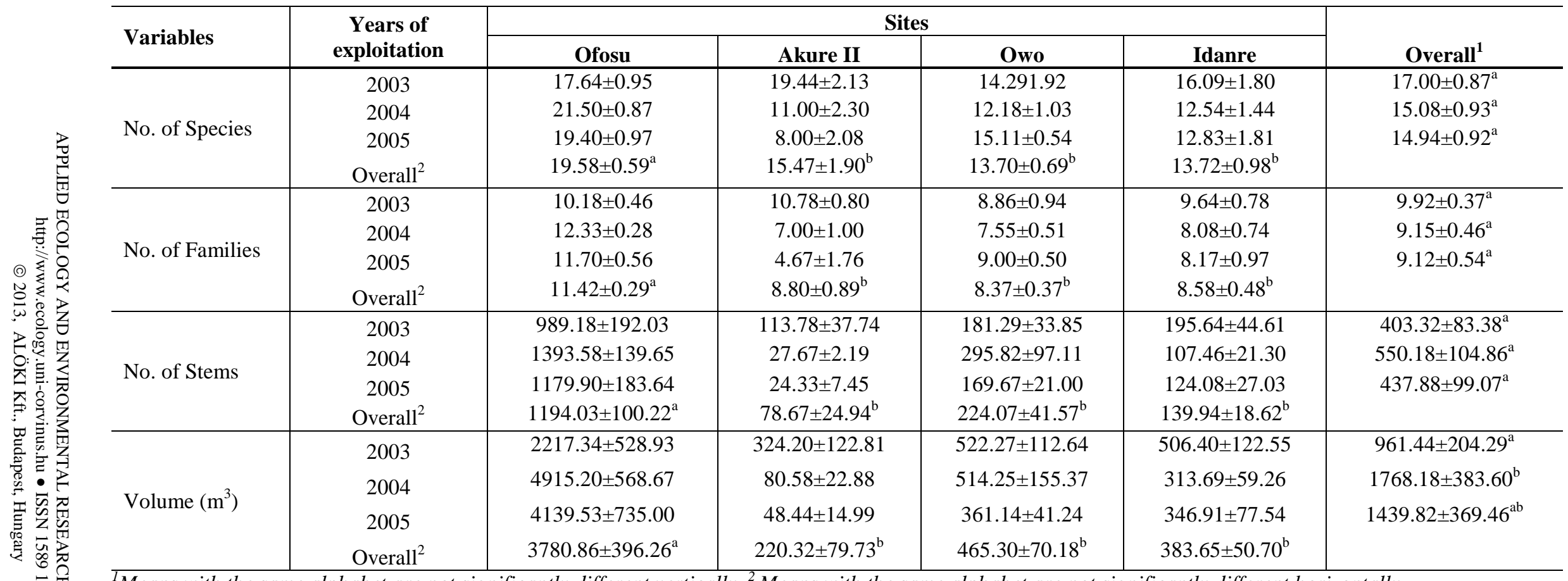

${ }^{1}$ Means with the same alphabet are not significantly different vertically, ${ }^{2}$ Means with the same alphabet are not significantly different horizontally 
The number (per hectare) of economic species has dwindled seriously in the tropical forest ecosystem. So, species that were of less recognition in the timber market and were less exploited in the past are found to be gaining popularity during the course of this study. Virtually all species were logged in the study area during the study period. Oyagade (1997) reported that the worsening shortages of the primary species like Melicia excelsa and Khaya spp has made way for the lesser-used species such as Ceiba pentandra, Celtis zenkeri, Brachystegia nigerica, Sterculia rhinopetala, etc which are now becoming available in the timber market. These lesser-utilized species has low density and are moderately durable. Despite their shortcoming, they are now competing with Melicia excelsa, Khaya spp, etc in the timber market. The results of this study also indicated that some species were not found in the free areas again. These species were those exclusively exploited in the reserves. Some of these species are Afzelia africana, Cordia millenii, Lovoa trichilioides, Mansonia altissima, Mitragyna ciliata, Nauclea diderrichii, Nesogordonia papaverifera and Sterculia rhinopetala.

The wide discrepancy in the number of stems and also in volumes of trees exploited from month to month shows the impacts of climatic conditions on logging activities in the tropic. It was observed that timber exploitation was more intense during the dry season and in the months when rainfall was less frequent. Timber exploitation drastically reduced as rainfall became more intense. This account for why logging was less active in July. Nigeria, a developing country in the tropic has bad roads and poor road network. The roads are usually untarred therefore not motorable especially to timber trucks throughout the year. The tropical ecological zone of southwest Nigeria where this study was carried out is characterized with heavy rainfall and long rainy season (March to September with a break in August). The dry season is shorter (October to February). During this season, the roads are destroyed by erosion, flood and seasonal streams making access to the forest to be very difficulty. These are great impediments to logging, skidding, and transportation of logs. So loggers take the advantage of the dry season to exploit more trees.

There is general increase in the number of stems and volume of timber exploited from the free areas and forest reserves between 2003 and 2004 but a decrease between 2004 and 2005. This is an indication of the decrease in the number and size of merchantable timbers as a result of pressure on the forest estate. Nigeria that was formerly an exporter of wood and high grade timber has now become an importer of wood. The astronomical increase in population has subsequently increased the demand for forest land and forest products. Encroachment, plantation development, farming, indiscriminate fire and construction works are some of the activities destroying the forest ecosystem and subsequently making the quantity and quality of merchantable $\operatorname{logs}$ to decrease. The current level of demand for wood is more than the sustainable level of supply. What is removed is far beyond the natural capacity of the forest to recuperate in order to continue its normal functions (Olajide et al., 2008). The projected level of supply and demand for wood indicates that from year 2005 to 2020, there is the possibility of an annual deficit of about 80 million to 100 million $\mathrm{m}^{3}$ (Oyebo, 2006). The amount of money accruing form timber business to timber merchants and the government is very huge but little or nothing is ploughed back into the forest for development and regeneration.

The negative economical, ecological and environmental impacts of logging are very grave. Continuous exploitation without adequate regeneration strategies will lead to structurally and genetically degraded forest, which are extremely difficult and expensive 
to rehabilitate. It is highly urgent therefore that the government and all stakeholders in the forestry sub-sector to take bold step to reduce the present high rate of forest exploitation and increase forest regeneration. If this is not done, the whole forest estate stands the risk of finally being fully depleted in the next $5-10$ years (Adetula, 2008). This also calls for the revisiting and implementing the basic principles of sustainable forest management (SFM) which is the only way forward to safe Nigerian forest from total collapse and mitigate its numerous impacts.

For forest managers, sustainably managing a particular forest tract means determining, in a tangible way, how to use it today to ensure similar benefits, health and productivity in the future. Forest managers must assess and integrate a wide array of sometimes conflicting factors - commercial and non-commercial values, environmental considerations, community needs, and even global impact - to produce sound forest plans (FAO, 2001). SFM is a system of management that guarantees continuous exploitation of forest resources. It is governed by operational rules and regulations which allow the inexhaustible or everlasting existence of forest resources for future benefits and advantages. It seeks the promotion of long life survival of the forest, while making use of the forest in terms of resources extraction (Pampka, 2005). So, SFM has potential to eradicate poverty, reduce land degradation, increase food security and access to safe drinking water and provide affordable energy and other benefits. Managers, policy makers and all stakeholders in the forestry sub-sector need to collaborate and manage Nigerian forest resources judiciously to be able to avert the imminent problems of deforestation.

\section{Conclusion and recommendation}

This study examined the rate of logging in tropical rainforest ecosystem of south west Nigeria using Ondo State, Nigeria as a case study. The results indicated that virtually all indigenous tree species are now exploited as timbers from the reserves and free areas. There is sharp reduction in the availability of the most economic tropical hardwood species, so the lesser utilized ones are now in the timber market competing with the economic ones. Number of stems and species exploited from the free areas for the 3-year period was discovered to be more than what was exploited from the reserves in the four zones selected for this study. The volume of trees exploited in the reserves was also less than what came out of the free areas for the three-year period. This was attributed to the fact that there were no stringent conditions attached to logging in the free areas as in the reserves where all activities within are controlled by the state department of forestry. Loggers only pay necessary fees as stipulated in forest tariff on $\operatorname{logs}$ to be felled in the free areas. The present rate of wood removal from the forest is far more than the regeneration ability of the natural forest. This is very inimical to sustainable forest management. The tropical rainforest is therefore on the verge of total disappearance. The implications of this on rural livelihood, wood based industries; biodiversity conservation and environmental sustainability are very serious. So, SFM is potentially viable to reduce, if it cannot totally curb, this menace. The following recommendations are made for SFM to be actualized include proper forest governance; eradication of chronic corruption and bribery; anti illegal forest activities campaign; provision of adequate funding to support the forestry department for forest monitoring; efficient and effective control of all activities in the forest reserves and the free areas; 
embarking community based forest management system; review of forest laws; and plantation development.

\section{REFERENCES}

[1] Adekunle, V.A.J. (2006): Conservation of tree species diversity in tropical rainforest ecosystem of southwest Nigeria. - Journal of Tropical Forest Science 18(2): 91-101.

[2] Adetula, T. (2008): Challenges of Sustainable Forest Management in Ondo State: Community Based Forest Management System as a Panacea. - In: Onyekwelu, J.C., Adekunle, V.A.J., Oke, D.O., (eds) Research for development in forestry, forest products and natural resources management $\left(\right.$. The $1^{\text {st }}$ National Conference of the Forest and Forest Products Society held at the Federal University of Technology, Akure, Nigeria, $16^{\text {th }}-18^{\text {th }}$ April, 2008. P242-247.

[3] Agbeja, B.O., Adesoye, P.O., Adu-Anning, C., Abdoulaye, T. (2005): Assessment Of Joint Forest Management.

[4] Briner, J.D. (2004): Strong Policy through National Consensus: Canada's Forestry Policy Experiment. - In: the Proceedings of the Conference on Policy Instruments for Safeguarding Forest Biodiversity - Legal and Economic Viewpoints. The Fifth International BIOECON Conference, 15th-16th January 2004, House of Estates, Helsinki /Working Papers of the Finnish Forest Research Institute 1, ed. P. Horne et al., Finnish Forest Institute, Helsinki, pp. 131-142.

[5] Brown, K.A., Gurevitch, J. (2004): Long-term Impacts of Logging on Forest Diversity in Madagascar. - PNAS 2004 101(16), 6045-6049.

[6] Castañeda, Christel Palmberg-Lerche, Petteri Vuorinen, May (2001): Forest Management Working Papers, Working Paper 5. - Forest Resources Development Service, Forest Resources Division. FAO, Rome.

[7] Falaye, T.A., Oluyege, A.O., Olufemi, B., Fuwape, J.A. (2006): Timber Exploitation Pattern in the Forests of Ekiti State, Nigeria from 1996-2001. - Proceedings of $2^{\text {nd }}$ Annual Conference of School of Agriculture and Agricultural Technology, Federal University of Technology, Akure, Nigeria, $24^{\text {th }}$ May, 2006. pp 87-93.

[8] FAO (2001): Criteria and Indicators for Sustainable Forest Management: A Compendium. - Paper compiled by Froylán.

[9] FORMECU (1999): Forest Resources Study, Nigeria. - Forest Resources Main Report 1:2-21, 3-1-3-7.

[10] Fuwape, J.A. (2001): The Impacts of Forest Industries and Wood Utilization on the Environment. - ODSG-FAN CONSULT Workshop on Forest industries, Environment and Sustainable Development. JTFR 17(2): 78-90.

[11] Ogunlade, A.B. (1993): The Needed Strategies and Problems of Industrial Plantation Development in Nigeria. - In: Oduwaye, E.A. (ed.) Proceeding of 23rd Ann. Conf. of FAN, Dec., 1993, p.87.

[12] Okpo (1996): Personal Communication. - In: Meregini, A.O.A.: Timber Production in Cocoa Based Agroforestry Systems in Parts of Abia State, Nigeria. Proceedings of the $25^{\text {th }}$ Annual Conference of the Forestry Associations of Nigeria. pp 103.

[13] Olajide, O., Etigale, E.B., Udofia, S.I. (2008): Wood-Based Industries and Sustainable Production of Industrial Wood Raw Material in Nigeria. - In: Onyekwelu, J.C., Adekunle, V.A.J., Oke, D.O. (eds.) Research for development in forestry, forest products and natural resources management. The $1^{\text {st }}$ National Conference of the Forest and Forest Products Society held at the Federal University of Technology, Akure, Nigeria, $16^{\text {th }}-18^{\text {th }}$ April, 2008. p.212-215.

[14] Onyekwelu, J.C., Adekunle, V.A.J., Adeduntan, S.A. (2005): Does Tropical Rainforest Ecosystem Possess the Ability to Recover from Severe Degradation? - In: Popoola, L., Mfon, P., Oni, P.I. (eds) Sustainable Forest Management in Nigeria: Lessons and 
Prospects, Proceeding of the $30^{\text {th }}$ Annual Conference of the Forestry Association of Nigeria, Kaduna, Nigeria. $07^{\text {th }}-11^{\text {th }}$ Nov. 2005, p.145-163.

[15] Oyagade, A.O. (1997): Nigerian Rainforest Conservation: The Challenge to the WoodBased Sector. Proceedings of the $25^{\text {th }}-$ Annual Conference of the Forestry Associations of Nigeria. pp 302-303.

[16] Oyebo, M.A. (2006): History of forest management in Nigeria from $19^{\text {th }}$ century to date. - In: Ayobami, T.S (ed.) Imperatives of space technology for sustainable forest management. Proceedings of an international stakeholders' workshop sponsored by National Space Research and Development Agency held In Abuja, Nigeria between 27 and 28 March 2006, p. 1-14.

[17] Pampka, P.M. (2005): Sustainable Forest Management: Opportunities and Challenges for Nigeria. - In: Popoola, L., Mfon, P., Oni, P.I. (eds.) Sustainable Forest Management In Nigeria: Lessons and Prospects, Proceeding of the $30^{\text {th }}$ Annual Conference of the Forestry Association of Nigeria, Kaduna, Nigeria. $07^{\text {th }}-11^{\text {th }}$ Nov. 2005, p.1-17.

[18] Practices In West Africa (Case Study Of Nigeria, Ghana And Niger) - Nigeria Journal of Forestry 35(1): 32-40.

[19] Reich, P.B., Bakken, P. Carlson, D, Frelich, L.E., Friedman, S.K., Grigal, F.D. (2001): Influence of Logging, Fire, and Forest Type on Biodiversity and Productivity in Southern Boreal Forests. - Ecology 82(10): 2731-2748.

[20] Salami, A.T. (2006): Monitoring Nigerian forest with NigeriaSat-1 and other satellites. In: Ayobami, T.S. (ed.) Imperatives of space technology for sustainable forest management. Proceedings of an international stakeholders' workshop sponsored by National Space Research and Development Agency held In Abuja, Nigeria between 27 and 28 March 2006., p. 26-61.

[21] SPSS (2003): Statistical package for social sciences, 12.0 for windows. - SPSS Inc. Illinios, USA. 